\title{
Uptake of the child care expense deduction: exploring factors associated with the use of the child care expense deduction among families with a child under 12 years
}

\author{
Loanna Heidinger, Leanne C. Findlay ${ }^{*}$ (1) and Anne Guèvremont
}

\author{
*Correspondence: \\ Leanne.findlay@canada.ca \\ Health Analysis Division, \\ Applied Research Branch, \\ Statistics Canada, 100 \\ Tunney's Pasture Driveway, \\ Ottawa, ON K1A 0T6, Canada
}

\begin{abstract}
The Canadian government implemented the child care expense deduction in 1972, a policy initiative intended to offset the financial cost of child care for eligible families. Although the deduction has now been in place for almost 50 years, and almost half of all families with a child aged 0-14 years use child care (Sinha, 2014), little research has examined the factors associated with claiming the child care expense deduction. The current study examined the uptake and usage of the child care expense deduction among families with at least one child under the age of 12 in 2011. Furthermore, the family demographic and work characteristics of families who have at least one child under the age of 12 in the household were explored in terms of the characteristics associated with a higher likelihood of claiming the child care expense deduction.
\end{abstract}

\section{Background}

The child care expense deduction is a long running tax benefit that provides support to families with young children participating in child care in Canada. The deduction assists families by reducing the taxable income of claimant families (up to two-thirds of the claimant parent's income) who rely on child care services in order to earn income from work, attend school, or participate in grant-funded research. The deduction is generally claimed by the sole income earner in eligible single parent households or by the lowest income earner (including parents with no income) in eligible dual parent households. In order for families to claim the child care expense deduction, parents must obtain and retain valid receipts from child care providers indicating the full amount of child care paid for each child during the preceding tax year. Child care expenses include both licensed and unlicensed care provided at daycare centers, nursery schools, and in the home. Expenses also include day camps and lodging for overnight camps and boarding schools. Since implementation, the child care expense program has undergone some changes, including increases in the amount deductible per eligible child. For instance,

(c) The Author(s) 2020. This article is licensed under a Creative Commons Attribution 4.0 International License, which permits use, sharing, adaptation, distribution and reproduction in any medium or format, as long as you give appropriate credit to the original author(s) and the source, provide a link to the Creative Commons licence, and indicate if changes were made. The images or other third party material in this article are included in the article's Creative Commons licence, unless indicated otherwise in a credit line to the material. If material is not included in the article's Creative Commons licence and your intended use is not permitted by statutory regulation or exceeds the permitted use, you will need to obtain permission directly from the copyright holder. To view a copy of this licence, visit http://creativeco mmons.org/licenses/by/4.0/. 
in 1972 , the maximum amount that could be claimed was $\$ 500$; in 2010 , families were able to claim up to $\$ 7,000$ for an eligible child and $\$ 10,000$ for an eligible child with disabilities.

The potential benefits of the child care expense deduction are threefold. First, the expense deduction reduces the financial burden of child care by providing some direct relief for child care expenses by reducing the taxable income of claimant families. Recent results from the Canadian Survey on Early Learning and Child Care Arrangements (SELCCA) revealed that $40 \%$ of parents with children aged 0-5 chose their main child care arrangement based on affordability and $11 \%$ of respondents reported having difficulty finding affordable child care (Statistics Canada 2019). These findings are consistent with previous research that finds affordability of child care to be a priority for many parents seeking child care above other factors such as type and hours of care (National Survey of Early Care and Education Project Team 2014). In Canada, the cost of child care varies largely depending on the province and city in which children and their families live. Large metropolitan cities experience the highest costs of child care. For example, in 2016, the median cost of care in Toronto was approximately $\$ 1650$ per month for an infant and \$1375 per month for a toddler (Macdonald and Friendly 2018). Comparatively, in Saskatoon, the median cost of child care per month per infant and toddler, respectively, was $\$ 850$ and $\$ 740$. Research finds that overall costs of child care continue to increase annually (Macdonald and Friendly 2014). Increasing the affordability of child care might reduce the financial barrier to access experienced by some families.

Second, the child care expense deduction may encourage parents to enter the labour force and may have a positive impact on the labour force participation of mothers with young children, since earned income is a condition of benefiting from this tax benefit. The decision for mothers to work or return to the labour force following child birth is largely shaped by child care provision and affordability (Cleveland et al. 1996). In some large metropolitan cities in Canada, studies indicate that working mothers can spend over 30\% of their pre-tax income on child care (Macdonald and Friendly 2014). Furthermore, mothers with young children may participate in the labour market differently than persons without children or with older school-aged children. For example, mothers are more likely to go on leave from paid work to care for young children and/or may work less stable jobs, reduced hours, or non-standard shifts to further accommodate child care responsibilities.

The province of Quebec provides an example of how maternal employment may be shaped by the provision of child care. In 1997, a universal child care policy was implemented in Quebec with the goal of providing affordable, subsidized child care, and increasing the availability of child care spaces for children less than 5 years of age. By 2000, all children less than 60 months were eligible to participate in the program (Lefebvre et al. 2009). The implementation of the policy had a positive impact on maternal employment rates in Quebec, with increases in both the number of weeks worked and overall labour force participation, especially for more educated mothers (Haeck et al. 2015).

Third, the expense deduction may indirectly support young children's participation in early learning and child care programs, which, when they are of high quality, have been associated with positive outcomes (Melhuish et al. 2015). Early enrollment in 
developmentally appropriate child care programs can lead to the development of cognitive and achievement skills that increase school readiness, such as language, literacy, and mathematics (Yoshikawa et al. 2013). Some studies further find a positive impact on socio-emotional development for children who attend child care programs. Stability and quality of care are important predictors of the positive benefits of enrollment in child care for children, with larger gains experienced by children in higher quality programs.

Thus, the child care expense deduction is intended to provide support for parents using child care to earn income and may reduce economic barriers that hinder the use of child care, specifically among more disadvantaged families. However, previous literature on the uptake and usage of tax credits and deductions suggests that tax credits and deductions may be underused by families most in need (Spence et al. 2010). There are two main reasons that low income families may be less likely to apply for the child care expense deduction. First, the value of the deduction is tied to earning an income and is bound to the income limit. The expense deduction reduces the taxable income for the lowest income earning parent (or lone parent) and the deducted amount cannot exceed two-thirds of the claimant parent's income. Therefore, parents must earn an income, in particular an income that exceeds the full amount paid for child care for a given tax year, to reap the benefits of the expense deduction. However, lower income families may not earn enough to claim partial or full amounts of child care expenses and would receive little-to-no benefit from applying for the deduction (Gagné 2001; Prentice and White 2018). Second, the expense deduction is received at the end of the tax year, possibly months after taxes are filed, potentially favouring families that are able to cover the costs of child care upfront. Low-income families may not have the funds necessary to pay for child care at the time of use.

Limited research exists on the child care expense deduction, in particular on the uptake of the expense deduction and the family factors associated with the use of the expense deduction. The current study uses the General Social Survey on Families linked to administrative data (family tax files) to assess the demographic and employment characteristics of families claiming the child care expense deduction in Canada. These results provide a more complete understanding of the uptake and usage of the child care expense deduction among eligible Canadians.

\section{Methods}

\section{Data sources and definitions}

The current report utilizes linked secondary data from the 2011 (Cycle 25) General Social Survey Families (GSS Families) and the 2010 T1 Family File (T1FF). The linkage of administrative tax data to population survey data provides a unique opportunity to assess valuable administrative information in the context of socioeconomic and demographic characteristics.

The GSS is a cross-sectional and independent social survey that collects data annually from a representative sample of households across the ten Canadian provinces. The scope of data collection does not include residents from the three Canadian Territories (Northwest Territories, Nunavut, and Yukon) or institutionalized persons. The GSS follows social trends and provides information on the well-being and living conditions of 
Canadian families, and informs various social policy issues across Canada. Along with the comprehensive sociodemographic information collected annually, each wave of the GSS focuses on a core topic. Families was first the core topic for the GSS in 1990 and has been a repeated topic of interest approximately every 5 years thereafter.

Data for the 2011 GSS were collected using Computer-Assisted Telephone Interviewing (CATI). Random Digit Dialing Method (RDDM) was used to randomly generate a list of home phone numbers to select a representative sample of Canadian households. Respondents from the selected households were invited to participate in the telephone questionnaire if they were 15 years or older. No interviews by proxy were allowed and each participant provided personal consent to respond to the survey. The overall response rate of the 2011 GSS was approximately $66 \%$ and produced an unweighted sample of 22,435 respondents.

The T1FF data file is a databank of tax records grouped into census families, defined as a family comprised of parents and children living in the same household (Statistics Canada 2011). Individual and T4 employer tax records are collected and updated annually when persons file a personal tax return in the spring following the previous tax year. Tax data are matched in a family formation process, using information such as home address, to create the bank of data for census families. Annual T1FF data from 1982 to 2013 were linked to the 2011 GSS; however, for the current report, only data from the 2010 T1FF are utilized as it aligns with the collection period of the 2011 GSS. Since the T1FF utilizes administrative tax records, the data encompass a large proportion of the total Canadian population for a given tax year. In 2010, T1FF records represented 95\% of the Canadian population, including all Canadians that filed a tax return for the year (74\%) and non-filers residing in the same household derived from other data.

Data linkage was completed by Statistics Canada. Personal identifiers were used to directly link respondent records. In cases where there was no direct match, a process of deterministic record linkage was applied to identify participants based on non-missing identifiers. Overall, the linkage rate was approximately $91 \%$. Linkage rates were less successful among younger, single, minority, less educated, and low-to-no income persons. Separate weights were created for the linked survey (person weights, household weights, and bootstrap weights) to adjust for respondents with no successful linkage. Respondents were notified of the planned linkage before and during the survey. Any respondents who objected to the linkage of their data had their objections recorded, and no linkage to their tax data took place.

\section{Sample}

The analytic sample is comprised of all families with at least one child under the age of 12 living in the household part-time or full-time. Although parents can claim the child care expense deduction for children under 16, analyses (not shown) determined that the use of child care for children aged 12-14 was quite low, and data on child care were not available for children over the age of 14 . Therefore, only families with children under 12 were included in the analytic sample.

Although the child care expense deduction reduces the taxable income for eligible tax payers that pay for child care, this study did not restrict the analytic sample to working parents who reported the use of child care in the 2011 GSS. Instead, all families with a 
child in the age range of interest were included in the analysis. By including all families with at least one child under the age of 12 , the sample size was maximized for analyses and predictive power was maintained to ensure that results are reliable and comply with the confidentiality requirements of the Statistics Act as outlined by Statistics Canada.

Furthermore, by considering a broader sample, important family characteristics can be compared between families claiming the child care expense deduction and those not claiming the child care expense deduction. The inclusion of all families with children under 12 enables the exploration of the demographic and work characteristics associated with claiming the expense deduction among all families with at least one child under the age of 12 .

Finally, this approach accounts for any potential discrepancies in reporting the use of child care in the 2011 GSS and claiming the child care expense deduction for the 2010 tax year. Families completed the 2011 GSS between January and December of 2011, which means the reporting period for child care use (in the last year) overlapped to varying extents with the 2010 tax year. Families who claimed the child care expense deduction when filing taxes for the previous tax year may not have indicated child care use in the GGS due to the time lag in data collection periods.

There were a total of 3,786 families included in the analytical sample, representing approximately 2,847,738 families across Canada.

\section{Variables}

\section{Child care expense deduction}

The outcome of interest in the current study was whether a family claimed the child care expense deduction. Family claimant status was obtained from the 2010 T1FF dataset.

Various family characteristics potentially associated with claiming the child care expense deduction were obtained from the 2011 GSS and examined in the analyses, in particular, measures of family demographic, child composition, and employment characteristics.

\section{Demographic characteristics}

\section{Family composition}

Whether the family was a lone-parent or two-parent household was determined using the respondent's marital status. Lone-parent households were comprised of families where the respondent indicated that they were single, separated, divorced, or widowed. Two-parent households were composed of families where the respondent indicated that they were married or living common law.

\section{Highest household education}

Information on respondents and, for two-parent households, spouse's highest level of education was collected in the GSS. Data were combined and the education of the parent with the highest level of education was selected to represent the highest level of education in the household. Categories were dichotomous: highest level of education in the 
household less than a Bachelor's degree versus highest level of education in the household a Bachelor's degree or more.

\section{Adjusted household income quartiles}

Household income was used to calculate income quartiles and was adjusted for family size by dividing income by the square root of the number of people residing in the household. Quartiles were determined within the analytic sample.

\section{Family Indigenous identity}

In the GSS, respondents self-reported on their and, for two-parent households, their spouse's Indigenous status. Responses were combined to create a dichotomous familylevel indicator of Indigenous parent(s) in the household: at least one parent Indigenous versus no parent Indigenous. Indigenous lone parents are included in at least one parent Indigenous; non-Indigenous lone parents are included in no parent Indigenous. Indigenous identifiers of First Nations, Métis, and Inuit were also considered separately; however, the sample was too small to report and thus distinction-based Indigenous identifier variables were not included in subsequent analyses.

\section{Family visible minority status}

The GSS collected information on whether respondents and, for two-parent households, their spouse identified as a visible minority. A family visible minority status variable was created by combining responses: both parents visible minority, one parent visible minority and one parent not, neither parent visible minority. Visible minority lone parents are included in the both parents visible minority category and non-visible minority lone parents are included in the neither parent visible minority category.

\section{Family immigrant status}

The GSS has information on the birth place of respondents and, for two-parent households, their spouse. Respondents (or spouses) not born in Canada were considered immigrants. Respondent and spouse information were combined to create a family-level measure of immigrant status: both parents immigrants, one parent immigrant and one parent not, both parents Canadian-born. Lone-parent immigrants were grouped with both parents immigrants, and non-immigrant lone parents were grouped with both parents Canadian-born.

\section{Area of residence}

Whether a family resided in an urban or rural area was based on Statistics Canada's Statistical Area Classification of postal codes used to geographically differentiate areas across Canada. Families were considered urban if they resided in a census metropolitan area (CMA) or a census agglomeration (CA); families were considered rural if they resided in any type of metropolitan influenced zone (MIZ).

\section{Province of residence}

Geography was also represented by the province in which the family resided. 


\section{Child composition}

Four summary variables were created to determine the distribution of children in the household among families with at least one child under 12:1) the total number of children in the household (one child, two children, three or more children), 2) the total number of children in the household under 12 (one child, two children, three or more children), 3) whether or not there was a child in the household under the age of 6 (Yes, No), and 4) whether there was an additional child in the household aged 12-18 that could potentially provide child care for a younger sibling(s) (Yes, No).

\section{Employment characteristics}

Work variables of interest were available separately for both the GSS respondent and their spouse if married or common law. Variables included employment status (worked, did not work), hours worked (less than $30 \mathrm{~h}$ a week, 30-45 h a week, more than $45 \mathrm{~h}$ a week), and whether the hours of employment were standard (a regular day shift) or nonstandard (a regular evening shift, a regular night shift, a rotating shift, a split shift, on call, irregular schedule, or other). Variables were combined for respondents and spouses to create family-level variables that accounted for the employment characteristics of lone parents and both parents in the household. Family work variables considered were family employment status (lone or both parents work or in school, at least one parent not working or in school), family work hours (lone or both parents work more than $30 \mathrm{~h}$, other parent works less or more than $30 \mathrm{~h}$, at least one parent non-working), and family standard employment (lone or both parents work standard jobs, both parents work but one or both parents work non-standard jobs, at least one parent non-working). Nonworking lone parents were included in the at least one parent non-working category.

Variables with non-significant differences between claimant and non-claimant families, indicated by Chi-square estimates with a $p$ value greater than 0.05 , were not included in the final analytic model. Due to high correlations among family work variables, only the variable family work hours was included in the final analytic model.

\section{Analytic strategy}

Descriptive analyses were conducted to provide the distribution of demographic, child composition, and work characteristics among the overall analytic sample of families with at least one child under the age of 12 . Subsequent descriptive statistics calculated the frequencies separately for families that claimed the child care expense deduction and families that did not claim the child care expense deduction.

Chi-square tests were used to estimate overall significant differences in the distribution of demographic, child composition, and work characteristics between families that claimed the child care expense deduction and families that did not claim the child care expense deduction.

Finally, logistic regression analyses were conducted to estimate factors associated with a higher likelihood of claiming the child care expense deduction. A series of stepwise models were estimated to examine the relative contribution of additional variables in the model (Model 1 includes the demographic variables only, Model 2 adds child composition, and Model 3 adds the work characteristic variables). All analyses were conducted using the SUDAAN plug-in for SAS 9.3. Bootstrap weights were utilized to account for the complex survey design. 
Exploratory analyses were conducted for families with at least one child under the age of 6 (see Appendices). However, since the T1FF is a family file, analyses were conducted at the level of the family and not the child. The T1FF provides information on whether or not a family claimed the child care expense deduction, but information is not provided on the specific child (or children) for whom the deduction was claimed. Therefore, it is not possible to disentangle the age of the child for which the claim was made in a household with multiple children. Thus, to avoid potential errors in estimation, the results and discussion focus on families with at least one child under the age of 12 .

Exploratory analyses were also conducted among a subsample of GSS families that reported using child care in the past 12 months. Overall, approximately $56 \%$ of all families with at least one child under the age of 12 reported using child care in the previous year. Among these families using child care, approximately a third (35\%) claimed the child care expense deduction. However, for reasons previously mentioned, results from the main analysis focus on the analytic sample composed of families with at least one child under the age of 12, regardless of reported child care use in the GSS.

\section{Results}

\section{Characteristics of child care expense deduction claimants}

Table 1 displays the characteristics of families with at least one child under the age of 12 and characteristics of families that claimed and did not claim the child care expense deduction for the 2010 tax year. Results from Chi-square tests are also presented indicating whether claimant families and non-claimant families were significantly different on the characteristics of interest.

Overall, less than a quarter (24\%) of families with at least one child under the age of 12 claimed the child care expense deduction. There were also significant differences in the characteristics of families who did and did not claim the child care expense deduction. That is, claimant families were more likely to be lone-parent families (35\% of single parent families claimed the child care expense deduction vs $22 \%$ of two-parent families), have the highest level of education in the household be a bachelor's degree or higher (29\% vs $20 \%$ of families with less than a Bachelor's degree), be in the highest income quartile (29\% vs $14 \%$ of families in the lowest income quartile), be non-Indigenous ${ }^{1}$ ( $25 \%$ vs $16 \%$ of Indigenous families), be non-visible minorities ( $25 \%$ vs $20 \%$ of visible minority families), be non-immigrants ( $26 \%$ and $20 \%$ of immigrant families), live in an urban area (25\% vs $19 \%$ of families who lived in a rural area), and live in Quebec (36\% vs $21 \%$ of families in Ontario).

In terms of family composition, claimant families were less likely to have three or more children ( $20 \%$ vs $26 \%$ of families with only one child) and to have an additional child aged $12-18$, supervisory age, living in the household ( $21 \%$ vs $25 \%$ of families with no additional child aged 12-18). Finally, in terms of family work characteristics, claimant families were more likely to work or attend school $(29 \%$ vs $7 \%$ of families where at least one parent was not in work or school), work standard hours (34\% vs $8 \%$ of families where at least one parent not working), and work full-time hours (30 h or more per week; $35 \%$ vs $8 \%$ of families where at least one parent not working).

${ }^{1}$ Indigenous Identifiers of First Nations, Métis, and Inuit were considered separately; however, the sample was too small to report and was not included in subsequent analysis. 
Table 1 Characteristics of families with at least one child less than 12 years old who did and did not claim the child care expense deduction

\begin{tabular}{|c|c|c|c|c|}
\hline & $\begin{array}{l}\text { Families with a } \\
\text { child less than } \\
12\end{array}$ & $\begin{array}{l}\text { Claimed child care } \\
\text { expense deduction }\end{array}$ & $\begin{array}{l}\text { Did not claim } \\
\text { child care expense } \\
\text { deduction }\end{array}$ & Chi square \\
\hline N & 3,786 & 933 & 2,853 & \\
\hline Weighted N & $2,847,738$ & 690,885 & $2,156,853$ & \\
\hline Weighted percent & 100.00 & 24.26 & 75.74 & \\
\hline \multicolumn{5}{|l|}{ Demographics } \\
\hline Family composition & & & & $25.36^{*}$ \\
\hline Two-parent household & 85.93 & 22.48 & 77.52 & \\
\hline Lone-parent household & 14.07 & 35.15 & 64.85 & \\
\hline $\begin{array}{l}\text { Highest education in house- } \\
\text { hold }\end{array}$ & & & & $31.26^{*}$ \\
\hline Bachelor's degree or higher & 46.06 & 28.88 & 71.12 & \\
\hline Less than a Bachelor's degree & 53.94 & 20.42 & 79.58 & \\
\hline $\begin{array}{l}\text { Adjusted family income } \\
\text { quartiles }\end{array}$ & & & & $19.13^{*}$ \\
\hline Lowest income quartile 1 & 17.93 & 13.59 & 86.41 & \\
\hline Income quartile 2 & 28.50 & 21.29 & 78.71 & \\
\hline Income quartile 3 & 25.96 & 29.54 & 70.46 & \\
\hline Highest income quartile 4 & 27.62 & 28.60 & 71.40 & \\
\hline Family Indigenous status ${ }^{1}$ & & & & $9.16^{*}$ \\
\hline $\begin{array}{l}\text { At least one parent Indig- } \\
\text { enous }\end{array}$ & 5.22 & $16.12^{\mathrm{E}}$ & 83.88 & \\
\hline No parent Indigenous & 94.78 & 24.69 & 75.31 & \\
\hline Family visible minority status & & & & $4.03^{*}$ \\
\hline $\begin{array}{l}\text { Lone or both parents visible } \\
\text { minority }\end{array}$ & 15.92 & 19.95 & 80.05 & \\
\hline $\begin{array}{l}\text { One parent visible minority, } \\
\text { other parent non-visible } \\
\text { minority }\end{array}$ & 5.88 & $19.58^{\mathrm{E}}$ & 80.42 & \\
\hline $\begin{array}{l}\text { Lone or neither parent visible } \\
\text { minority }\end{array}$ & 78.20 & 25.49 & 74.51 & \\
\hline Family immigrant status & & & & $3.50^{*}$ \\
\hline $\begin{array}{l}\text { Lone or both parents immi- } \\
\text { grants }\end{array}$ & 19.36 & 20.42 & 79.58 & \\
\hline $\begin{array}{l}\text { One parent immigrant, } \\
\text { one parent Canadian born }\end{array}$ & 10.77 & 22.40 & 77.60 & \\
\hline $\begin{array}{l}\text { Lone or both parents Cana- } \\
\text { dian born }\end{array}$ & 69.87 & 25.64 & 74.36 & \\
\hline Area of residence & & & & $14.07^{*}$ \\
\hline Urban & 81.73 & 25.43 & 74.57 & \\
\hline Rural & 18.27 & 19.02 & 80.98 & \\
\hline Province & & & & $9.44^{*}$ \\
\hline $\mathrm{NL}$ & 1.34 & $13.83^{\mathrm{E}}$ & 86.17 & \\
\hline PE & 0.38 & $28.07^{\mathrm{E}}$ & 71.93 & \\
\hline NS & 2.43 & 21.95 & 78.05 & \\
\hline NB & 2.06 & 28.11 & 71.89 & \\
\hline$Q C$ & 23.33 & 36.1 & 63.89 & \\
\hline ON & 37.57 & 20.65 & 79.35 & \\
\hline $\mathrm{MB}$ & 3.31 & 23.70 & 76.30 & \\
\hline SK & 2.97 & 17.88 & 82.12 & \\
\hline$A B$ & 12.96 & 19.07 & 80.93 & \\
\hline$B C$ & 13.66 & 21.15 & 78.85 & \\
\hline
\end{tabular}


Table 1 (continued)

\begin{tabular}{|c|c|c|c|c|}
\hline & $\begin{array}{l}\text { Families with a } \\
\text { child less than } \\
12\end{array}$ & $\begin{array}{l}\text { Claimed child care } \\
\text { expense deduction }\end{array}$ & $\begin{array}{l}\text { Did not claim } \\
\text { child care expense } \\
\text { deduction }\end{array}$ & Chi square \\
\hline \multicolumn{5}{|l|}{ Children in household } \\
\hline Total number of children & & & & $4.65^{*}$ \\
\hline 1 & 33.71 & 25.79 & 74.21 & \\
\hline 2 & 45.15 & 25.06 & 74.94 & \\
\hline $3+$ & 21.13 & 20.11 & 79.89 & \\
\hline $\begin{array}{l}\text { Total Number of Children } \\
\text { under } 12\end{array}$ & & & & 1.90 \\
\hline 1 & 48.95 & 24.52 & 75.48 & \\
\hline 2 & 39.60 & 25.05 & 74.95 & \\
\hline $3+$ & 11.45 & 20.43 & 79.57 & \\
\hline At least one Child under 6 & & & & 0.06 \\
\hline Yes & 62.46 & 24.11 & 75.89 & \\
\hline No & 37.54 & 24.52 & 75.48 & \\
\hline $\begin{array}{l}\text { Additional child 12-18 poten- } \\
\text { tial to } \\
\text { supervise }\end{array}$ & & & & $7.30^{*}$ \\
\hline Yes & 21.47 & 20.55 & 79.45 & \\
\hline No & 78.53 & 25.28 & 74.72 & \\
\hline \multicolumn{5}{|l|}{ Family work characteristics } \\
\hline Family work/in school & & & & $207.59^{*}$ \\
\hline $\begin{array}{l}\text { Lone or both parents work/ } \\
\text { in school }\end{array}$ & 76.99 & 29.38 & 70.62 & \\
\hline $\begin{array}{l}\text { At least one parent no work/ } \\
\text { in school }\end{array}$ & 23.01 & 7.14 & 92.86 & \\
\hline Family work schedule & & & & $117.94^{*}$ \\
\hline $\begin{array}{l}\text { Lone or both parents stand- } \\
\text { ard work }\end{array}$ & 43.70 & 34.44 & 65.56 & \\
\hline $\begin{array}{l}\text { One parent standard work, } \\
\text { one parent non-standard } \\
\text { work }\end{array}$ & 30.93 & 23.89 & 76.11 & \\
\hline $\begin{array}{l}\text { At least one parent not } \\
\text { working }\end{array}$ & 25.37 & 7.66 & 92.34 & \\
\hline Family work hours & & & & $124.29^{*}$ \\
\hline $\begin{array}{l}\text { Lone or both parents work- } \\
\text { ing } 30+\text { hrs }\end{array}$ & 52.01 & 34.92 & 65.08 & \\
\hline $\begin{array}{l}\text { Lone or one parent working } \\
<30 \text { hrs, } \\
\text { one parent }<30 \text { or } 30+\text { hrs }\end{array}$ & 20.19 & 22.58 & 77.42 & \\
\hline $\begin{array}{l}\text { At least one parent not } \\
\text { working }\end{array}$ & 27.80 & 7.66 & 92.34 & \\
\hline \multicolumn{5}{|c|}{ Source: General Social Survey 2011 linked to T1FF } \\
\hline \multicolumn{5}{|c|}{ E Use with caution } \\
\hline \multicolumn{5}{|c|}{ F Too unreliable to be published } \\
\hline \multicolumn{5}{|c|}{ XSupressed to meet the confidentiality requirements of the Statistics Act } \\
\hline \multicolumn{5}{|c|}{${ }^{*} p<0.05$} \\
\hline${ }^{1}$ Indigenous Identity of First Nations & Métis, and Inuit alsc & nsidered; however, samp & & \\
\hline
\end{tabular}

Table 2 presents results from the logistic regression model predicting whether or not families claim the child care expense deduction among all families with a child under the age of 12 controlling for differences in key demographic, child composition, 
Table 2 Logistic regression predicting claimants of the child care expense deduction among families with a child less than 12

\begin{tabular}{|c|c|c|c|}
\hline & Model 1 & Model 2 & Model 3 \\
\hline & Odds ratio & Odds ratio & Odds ratio \\
\hline Intercept & 0.71 & 0.53 & 0.66 \\
\hline \multicolumn{4}{|l|}{ Family composition } \\
\hline Two-parent household (REF) & 1.00 & 1.00 & 1.00 \\
\hline Lone-parent household & $3.28^{*}$ & $3.37^{*}$ & $2.64^{*}$ \\
\hline \multicolumn{4}{|l|}{ Highest Education in Household } \\
\hline Bachelor's degree or higher (REF) & 1.00 & 1.00 & 1.00 \\
\hline Less than a Bachelor's degree & $0.65^{*}$ & $0.66^{*}$ & $0.69^{*}$ \\
\hline \multicolumn{4}{|l|}{ Adjusted Family Income Quartiles } \\
\hline Lowest income quartile 1 & $0.33^{*}$ & $0.33^{*}$ & $0.58^{*}$ \\
\hline Income quartile 2 & $0.69^{*}$ & $0.68^{*}$ & 0.79 \\
\hline Income quartile 3 & 1.04 & 1.03 & 1.12 \\
\hline Highest income quartile 4 (REF) & 1.00 & 1.00 & 1.00 \\
\hline \multicolumn{4}{|l|}{ Family Indigenous status ${ }^{1}$} \\
\hline At least one parent Indigenous & 1.19 & 1.19 & 0.93 \\
\hline No parent Indigenous (REF) & 1.00 & 1.00 & 1.00 \\
\hline \multicolumn{4}{|l|}{ Family Visible Minority Status } \\
\hline Lone or both parents visible minority & 0.80 & 0.80 & 0.81 \\
\hline One parent visible minority, other parent non-visible minority & 0.74 & 0.75 & 0.78 \\
\hline Lone or neither parent visible minority (REF) & 1.00 & 1.00 & 1.00 \\
\hline \multicolumn{4}{|l|}{ Family Immigrant status } \\
\hline Lone or both parents immigrants & 0.97 & 0.98 & 1.11 \\
\hline One parent immigrant, one parent Canadian-born & 1.06 & 1.06 & 1.12 \\
\hline Lone or both parents Canadian-born (REF) & 1.00 & 1.00 & 1.00 \\
\hline \multicolumn{4}{|l|}{ Area of residence } \\
\hline Rural & $0.75^{*}$ & $0.75^{*}$ & $0.76^{*}$ \\
\hline Urban (REF) & 1.00 & 1.00 & 1.00 \\
\hline \multicolumn{4}{|l|}{ Province } \\
\hline $\mathrm{NL}$ & $0.27^{*}$ & $0.27^{*}$ & $0.32^{*}$ \\
\hline$P E$ & 0.68 & 0.70 & 0.75 \\
\hline NS & $0.46^{*}$ & $0.46^{*}$ & $0.52^{*}$ \\
\hline NB & $0.64^{*}$ & $0.63^{*}$ & 0.69 \\
\hline QC (REF) & 1.00 & 1.00 & 1.00 \\
\hline ON & $0.44^{*}$ & $0.43^{*}$ & $0.49^{*}$ \\
\hline MB & $0.58^{*}$ & $0.59^{*}$ & $0.58^{*}$ \\
\hline SK & $0.41^{*}$ & $0.41^{*}$ & $0.49^{*}$ \\
\hline$A B$ & $0.42^{*}$ & $0.42^{*}$ & $0.48^{*}$ \\
\hline $\mathrm{BC}$ & $0.41^{*}$ & $0.41^{*}$ & $0.47^{*}$ \\
\hline \multicolumn{4}{|l|}{ Number of children in the household } \\
\hline 1 (REF) & & 1.00 & 1.00 \\
\hline 2 & & 1.08 & 1.19 \\
\hline $3+$ & & 1.13 & 1.25 \\
\hline \multicolumn{4}{|l|}{ Child 12-18 potential to supervise } \\
\hline No & & $1.32^{*}$ & $1.49 *$ \\
\hline Yes (REF) & & 1.00 & 1.00 \\
\hline
\end{tabular}


Table 2 (continued)

\begin{tabular}{|c|c|c|c|}
\hline & Model 1 & Model 2 & Model 3 \\
\hline \multicolumn{4}{|l|}{ Family work hours } \\
\hline Lone or both parents working $30+\mathrm{h}$ (REF) & & & 1.00 \\
\hline Lone or one parent working $<30 \mathrm{~h}$, one parent working $<30$ or $30+\mathrm{h}$ & & & $0.67^{*}$ \\
\hline At least one parent not working & & & $0.20^{*}$ \\
\hline
\end{tabular}

Source: General Social Survey 2011 linked to T1FF

${ }^{*} p<0.05$

${ }^{1}$ Sample of Indigenous Identity distinctions (First Nations, Métis, Inuit) too small to include in analysis

Family work variables (family working/in school and family work schedule) were not included in the final models due to high correlation with family work hours variable

Model 1: Demographic variables

Model 2: Demographic variables + child composition

Model 3: Demographic variables + child composition + family work characteristics

and employment characteristics of families. A number of sociodemographic variables remained significant. Lone parent families were more likely to have claimed the expense deduction, with lone parents having more than two times the odds of claiming the deduction compared to two-parent families. As well, the highest level of education in the household was significantly different between claimant and nonclaimant families. Families where the highest level of education was less than a bachelor's degree had two-thirds the odds of claiming the child care expense deduction compared to families where the highest level of education was a bachelor's degree or higher.

Adjusted family household income quartiles were also different between claimant and non-claimant families after controlling for key variables in the final analytic model. Low-income families, those in income quartile 1, had about three-fifths the odds of claiming the child care expense deduction than high-income families (the highest income quartile). Although claimant and non-claimant families differed by immigrant status, visible minority status and Indigenous identity in the descriptive analysis, once included in the final logistic regression model which examined all variables simultaneously, these demographic indictors were no longer significant predictors of families claiming the child care expense deduction. Families living in rural areas had three-quarters the odds of claiming the child care expense deduction compared to families living in urban areas.

Provincial differences remained a significant predictor of claimant families in the final model. Families that resided in Quebec had higher odds of claiming the child care expense deduction compared to families residing in all other Canadian provinces except for New Brunswick and Prince Edward Island. The odds that families residing in Ontario claimed the child care expense deduction were half the odds of claiming for families residing in Quebec.

In the descriptive analysis, the percentage of participants claiming the child care expense deduction differed by the total number of children in the household; however, not by the total number of children under the age of 12 in the household or whether there was a child in the household under the age of 6 . In the final analytic model including key variables, having a child in the household between the ages of 12 
and 18 remained significant. The odds of claiming the child care expense deduction were 1.5 times higher for families without a child between the ages of 12-18.

Finally, child care expense claiming and non-claiming families differed by the work characteristics of parents. Only family work hours (lone or both parents work more than $30 \mathrm{~h}$, lone or one parent works less than $30 \mathrm{~h} /$ other parent works less than $30 \mathrm{~h}$ or more than $30 \mathrm{~h}$, at least one parent non-working) were included in the final analytic model due to the high correlation of family work hours with family employment status and family standard employment variables.

Compared to families with lone or two parents working $30 \mathrm{~h}$ or more a week, families with at least one parent not working and families with lone or one parent working less than $30 \mathrm{~h}$ and the other parent working (less/more than $30 \mathrm{~h}$ a week) had lower odds of claiming the child care expense deduction. Families where at least one parent was not working had one-fifth the odds of claiming the child care expense deduction, and families where lone or one parent was working less than $30 \mathrm{~h}$ and the other parent was working less/more than $30 \mathrm{~h}$ per week had two-thirds of the odds of claiming the child care expense deduction than families where lone or both parents were working more than $30 \mathrm{~h}$ a week. In other words, families where lone or both parents worked more than $30 \mathrm{~h}$ a week had higher odds of claiming the child care expense deduction.

\section{Discussion}

The child care expense deduction is an initiative aimed at providing financial support for families with young children participating in child care by proving tax credits for applicant families. The expense deduction reduces the taxable income of applicant parents, and is of value to parents using child care to earn income, attend school, or conduct grant-funded research. As such, the deduction may have a positive impact on the employment decisions of parents with young children, in particular mothers.

The current study is one of the first to assess the usage of the child care expense deduction and is unique in the examination of the use of the expense deduction in the context of family demographic and work characteristics. Utilizing linked data, analyses explored differences between claimant and non-claimant families, identifying characteristics of families associated with a higher likelihood of claiming the child care expense deduction. Overall, results indicated that there were demographic, child composition, and employment differences between claimant and non-claimant families, and suggested that certain families may be less likely to apply for the child care expense deduction.

A relatively small proportion of families claimed the child care expense deduction in Canada; less than a quarter of families with at least one child under the age of 12 in 2011 claimed the child care expense deduction during the 2010 tax year. The 2011 GSS collected data on the use of child care and approximately $56 \%$ of families in the analytic sample, families with at least one child under 12, reported using child care. Among these families that reported using child care, approximately a third (35\%) claimed the child 
care expense deduction, indicating that even among families that reported the use of child care, the proportion of families claiming the child care expense deduction remains relatively small. Additional analyses (available upon request) controlled for family child care use in the final analytic model and revealed similar results.

Differences in the use of child care and parental work schedules may account for a portion of families that did not claim the expense deduction. In particular, families that rely on unpaid informal care provided by family members or friends and families where one or both parents are not working may be unable to claim the expense deduction. However, a recent report by Findlay and Kohen (2019) revealed that 25\% of working parents that reported to have paid for child care did not claim the child care expense deduction in 2010, indicating that child care preferences and parental work schedules do not fully account for the reason families do not claim the expense deduction.

There are several potential reasons why families may not claim the expense deduction. First, non-claiming families may participate in paid child care arrangements that do not provide the formal documentation, such as receipts, necessary for claiming the tax deduction. Moreover, non-claimant families may lack knowledge of the child care expense deduction, may perceive a high level of complexity in applying for the deduction, or may perceive the deduction as inconvenient or non-beneficiary (Financial Accountability Office of Ontario 2019). Further still, it is possible that demographic characteristics of families may contribute to differences in claiming the expense deduction.

The current study found that differences in the likelihood of claiming the child care expense deduction were associated with demographic, child composition, and employment characteristics of families. Lone-parent families, families living in Quebec, and families with higher levels of household education and higher household incomes were more likely to claim the expense deduction. Claimant families were also less likely to have an additional child aged 12-18 in the household and were more likely to have parents that worked $30 \mathrm{~h}$ or more per week.

Families residing in Quebec were more likely to claim the child care expense deduction than most other provinces in Canada. Previous research indicates that the proportion of families using child care is not consistent across provinces, with the province of Quebec reporting the highest use of child care across the Canadian provinces (Statistics Canada 2019). Child care is regulated at the provincial level and province-specific policies and programs may influence child care use. The higher proportion of claimants in Quebec may reflect the higher rates of child care use in Quebec and province-specific programs, such as universal child care, that may encourage parents to utilize paid child care. 
Families with higher levels of education and higher household income were more likely to claim the child care expense deduction. These results mirror findings on the uptake of the former Children's Fitness Tax Credit in Canada that revealed that families with a higher income were more likely to know about and claim the Children's Fitness Tax Credit (Spence et al. 2010). Lower income families may be more likely to have a non-working parent or parents with an income that is less than the income amount necessary to benefit from the deduction. Lower income families may also be less likely to claim the full amount spent on child care, since claimant parents in low income families may be bound by the income limit, whereby the claimant parent cannot claim child care expenses that exceed two-thirds of their income (Laurin and Milligan 2017).

Families with a child aged 12-18 in the household were less likely to claim the child care expense deduction than families without a child aged 12-18 in the household. Families may rely on care by older siblings aged $12-18$, old enough to provide supervision to younger sibling(s) under the age of 12 , rather than using more formal types of paid child care.

Finally, as expected, since the value of the expense deduction is generally tied to earning an income, working families were more likely to claim the child care expense deduction. However, there were differences in the likelihood of claiming the expense deduction even among working parents. Families where a lone parent or both parents, in two-parent households, worked $30 \mathrm{~h}$ or more per week were more likely to claim the deduction than families that worked less than $30 \mathrm{~h}$ per week. Families that work fewer hours may be able to accommodate child care needs or may have more variable work schedules and may rely less on paid child care than parents who work full-time hours.

While this study provides valuable information on the use of the child care expense deduction among families in Canada, it is not without limitations. First, the data are from 2010 and 2011. More recent data were not available at the time of the study. However, since characteristics of families claiming the child care expense deduction have not been previously examined, this study provides a valuable contribution to the literature. Validating these results with more recent data would be possible if the GSS 2017 was to be linked with detailed 2016 tax information.

Second, the time frames of the two linked data sources do not exactly align, since the GSS was collected in 2011 and the T1FF represens data fromt 2010. However, focusing on families with a child under the age of 12 captures a larger proportion of claimant families in the analysis and further allows for comparisons across characteristics of claimant and non-claimant families.

Finally, the work and child care preferences of parents are unknown. It is unknown whether some parents choose to stay home and assume child care responsibilities or 
whether they prefer to be employed. Future research could assess the child care and work preferences of families with children under the age of 12, which may contribute to the variability in the likelihood of claiming the expense deduction.

\section{Conclusions}

The present study explored the demographic, child composition, and work characteristics that may provide insight into the reasons some families do not claim the child care expense deduction. Overall, results indicated that certain families may be less likely to claim the child care expense deduction, in particular lower educated families, lower income families, and families where parent(s) work less than full-time hours. The findings support the value of using linked data to supplement tax information with demographic characteristics and contribute to the understanding of the characteristics of families who claim the child care expense deduction in Canada.

\section{Declarations}

The General Social Survey 2011 data are available through Statistics Canada's Research Data Centres (statcan.gc.ca/eng/microdata/data-centres); however, the T1FF-linked files that support the findings of this study are not publically available. The authors declare that they do not have any competing interests. The research was funded through an agreement with Employment and Social Development Canada (ESDC). However, LH, LF, and AG were responsible for the study design, analysis, and interpretation of findings. The opinions expressed in this report are those of the authors and not Statistics Canada or ESDC. LH analyzed the data and was primarily responsible for writing the manuscript. LF and AG were involved in conceptualization of the project, writing, and reviewing the final manuscript.

\section{Appendices}

Appendix A

See Table 3. 
Table 3 Characteristics of families with at least one child less than 6 years old who did and did not claim the child care expense deduction

\begin{tabular}{|c|c|c|c|c|}
\hline & $\begin{array}{l}\text { Families with a } \\
\text { child less than } 6\end{array}$ & $\begin{array}{l}\text { Claimed child care } \\
\text { expense deduction }\end{array}$ & $\begin{array}{l}\text { Did not claim } \\
\text { child care expense } \\
\text { deduction }\end{array}$ & Chi square \\
\hline N & 2,223 & 559 & 1,664 & \\
\hline Weighted N & $1,778,769$ & 428,814 & $1,349,954$ & \\
\hline Weighted percentage & 100.00 & 24.11 & 75.89 & \\
\hline \multicolumn{5}{|l|}{ Family demographics } \\
\hline Family composition & & & & $7.00^{*}$ \\
\hline Two-parent household & 89.76 & 23.16 & 76.84 & \\
\hline Lone-parent household & 10.24 & 32.44 & 67.56 & \\
\hline $\begin{array}{l}\text { Highest education in house- } \\
\text { hold }\end{array}$ & & & & $28.75^{*}$ \\
\hline Bachelor's degree or higher & 48.07 & 29.67 & 70.33 & \\
\hline Less than a Bachelor's degree & 51.93 & 19.01 & 80.99 & \\
\hline $\begin{array}{l}\text { Adjusted family income } \\
\text { quartiles }\end{array}$ & & & & $12.88^{*}$ \\
\hline Lowest income quartile 1 & 18.56 & 12.98 & 87.02 & \\
\hline Income quartile 2 & 29.03 & 21.31 & 78.69 & \\
\hline Income quartile 3 & 23.42 & 29.79 & 70.21 & \\
\hline Highest income quartile 4 & 28.98 & 28.43 & 71.57 & \\
\hline Family Indigenous status & & & & $8.67^{*}$ \\
\hline $\begin{array}{l}\text { Lone or at least one parent } \\
\text { Indigenous }\end{array}$ & 5.04 & $14.18^{\mathrm{E}}$ & 85.82 & \\
\hline $\begin{array}{l}\text { Lone or neither parent } \\
\text { Indigenous }\end{array}$ & 94.96 & 24.61 & 75.39 & \\
\hline Family visible minority status & & & & 1.14 \\
\hline $\begin{array}{l}\text { Lone or both parents visible } \\
\text { minority }\end{array}$ & 16.09 & 22.33 & 77.67 & \\
\hline $\begin{array}{l}\text { One parent visible minority, } \\
\text { other parent non-visible } \\
\text { minority }\end{array}$ & 6.94 & $19.43^{\mathrm{E}}$ & 80.57 & \\
\hline $\begin{array}{l}\text { Lone or neither parent visible } \\
\text { minority }\end{array}$ & 76.97 & 24.86 & 75.14 & \\
\hline Family immigrant status & & & & 0.33 \\
\hline $\begin{array}{l}\text { Lone or both parents immi- } \\
\text { grants }\end{array}$ & 18.81 & 22.35 & 77.65 & \\
\hline $\begin{array}{l}\text { One parent immigrant, one } \\
\text { parent Canadian-born }\end{array}$ & 11.34 & 23.78 & 76.22 & \\
\hline $\begin{array}{l}\text { Lone or both parents } \\
\text { Canadian-born }\end{array}$ & 69.85 & 24.66 & 75.34 & \\
\hline Area of residence & & & & $5.69^{*}$ \\
\hline Urban & 81.86 & 25.11 & 74.89 & \\
\hline Rural & 18.14 & 19.59 & 80.41 & \\
\hline Region & & & & $5.18^{*}$ \\
\hline Atlantic & 5.76 & 25.28 & 74.72 & \\
\hline Quebec & 23.48 & 32.46 & 67.54 & \\
\hline Ontario & 36.48 & 21.45 & 78.55 & \\
\hline Prairie & 20.11 & 20.21 & 79.79 & \\
\hline British Columbia & 14.16 & 22.15 & 77.85 & \\
\hline \multicolumn{5}{|l|}{ Children in household } \\
\hline Total number of children & & & & 1.12 \\
\hline 1 & & 24.07 & 75.93 & \\
\hline 2 & & 25.39 & 74.61 & \\
\hline
\end{tabular}


Table 3 (continued)

\begin{tabular}{|c|c|c|c|c|}
\hline & $\begin{array}{l}\text { Families with a } \\
\text { child less than } 6\end{array}$ & $\begin{array}{l}\text { Claimed child care } \\
\text { expense deduction }\end{array}$ & $\begin{array}{l}\text { Did not claim } \\
\text { child care expense } \\
\text { deduction }\end{array}$ & Chi square \\
\hline $3+$ & & 21.55 & 78.45 & \\
\hline $\begin{array}{l}\text { Total number of children } \\
\text { under } 12\end{array}$ & & & & 0.93 \\
\hline 1 & & 24.36 & 75.64 & \\
\hline 2 & & 24.91 & 75.09 & \\
\hline $3+$ & & 21.23 & 78.77 & \\
\hline $\begin{array}{l}\text { Additional child 12-18 poten- } \\
\text { tial to } \\
\text { supervise }\end{array}$ & & & & 0.70 \\
\hline Yes & 8.01 & $21.53^{\mathrm{E}}$ & 78.47 & \\
\hline No & 91.99 & 24.33 & 75.67 & \\
\hline \multicolumn{5}{|l|}{ Family work characteristics } \\
\hline Family work/in school & & & & $137.19^{*}$ \\
\hline $\begin{array}{l}\text { Lone or both parents work/ } \\
\text { in school }\end{array}$ & 74.22 & 29.99 & 70.01 & \\
\hline $\begin{array}{l}\text { At least one parent no } \\
\text { work/in school }\end{array}$ & 25.78 & $7.18^{\mathrm{E}}$ & 92.82 & \\
\hline Family work schedule & & & & $77.66^{*}$ \\
\hline $\begin{array}{l}\text { Lone or both parents stand- } \\
\text { ard work }\end{array}$ & 41.46 & 34.67 & 65.33 & \\
\hline $\begin{array}{l}\text { One parent standard work, } \\
\text { one parent non-standard } \\
\text { work }\end{array}$ & 30.15 & 24.98 & 75.02 & \\
\hline $\begin{array}{l}\text { At least one parent not } \\
\text { working }\end{array}$ & 28.39 & 7.80 & 92.20 & \\
\hline Family work hours & & & & 81.71 \\
\hline $\begin{array}{l}\text { Lone or both parents work- } \\
\text { ing } 30+\text { hrs }\end{array}$ & 49.04 & 35.02 & 64.98 & \\
\hline $\begin{array}{l}\text { Lone or one parent working } \\
<30 \text { hrs, } \\
\text { one parent }<30 \text { or } 30+\text { hrs }\end{array}$ & 19.84 & 23.85 & 76.15 & \\
\hline $\begin{array}{l}\text { At least one parent not } \\
\text { working }\end{array}$ & 31.12 & 7.80 & 92.20 & \\
\hline
\end{tabular}

Source: General Social Survey 2011 linked to T1FF

E Use with caution

F Too unreliable to be published

XSupressed to meet the confidentiality requirements of the Statistics Act

${ }^{*} \mathrm{p}<0.05$

'Indigenous Identity of First Nations, Métis, and Inuit also considered; however, sample

too small to report

\section{Appendix B}

See Table 4 
Table 4 Logistic Regression Predicting Claimants of the Child Care Expense Deduction among Families with a Child less than 6 - Stepwise

\begin{tabular}{|c|c|c|}
\hline & Model 1 & Model 2 \\
\hline & Odds Ratio & Odds Ratio \\
\hline Intercept & 0.59 & 0.93 \\
\hline \multicolumn{3}{|l|}{ Highest education in household } \\
\hline Bachelor's degree or higher (REF) & 1.00 & 1.00 \\
\hline Less than a Bachelor's degree & $0.73^{*}$ & $0.72^{*}$ \\
\hline \multicolumn{3}{|l|}{ Adjusted family income quartiles } \\
\hline Lowest income quartile 1 & $0.43^{*}$ & 0.76 \\
\hline Income quartile 2 & 0.72 & 0.90 \\
\hline Income quartile 3 & 1.09 & 1.30 \\
\hline Highest income quartile 4 (REF) & 1.00 & 1.00 \\
\hline \multicolumn{3}{|l|}{ Family Indigenous status ${ }^{1}$} \\
\hline Lone or at least one parent Indigenous & 1.24 & 0.89 \\
\hline Lone or neither parent Indigenous (REF) & 1.00 & 1.00 \\
\hline \multicolumn{3}{|l|}{ Area of residence } \\
\hline Rural & 0.89 & 0.95 \\
\hline Urban (REF) & 1.00 & 1.00 \\
\hline \multicolumn{3}{|l|}{ Region } \\
\hline Atlantic & $0.68^{*}$ & 0.78 \\
\hline Quebec & 1.00 & 1.00 \\
\hline Ontario & $0.51^{*}$ & $0.60^{*}$ \\
\hline Prairie & $0.51^{*}$ & $0.62^{*}$ \\
\hline British Columbia & $0.52^{*}$ & 0.64 \\
\hline \multicolumn{3}{|l|}{ Family work hours } \\
\hline Lone or both parents working 30+ hrs (REF) & & 1.00 \\
\hline $\begin{array}{l}\text { Lone or one parent working }<30 \mathrm{hrs} \text {, } \\
\text { one parent working }<30 \text { or } 30+\text { hrs }\end{array}$ & & $0.63^{*}$ \\
\hline At least one parent not working & & $0.17^{*}$ \\
\hline
\end{tabular}

Source: General Social Survey 2011 linked to T1FF

${ }^{*} \mathrm{p}<0.05$

${ }^{1}$ Sample of Indigenous Identity distinctions (First Nations, Métis, Inuit) too small to

include in analysis

Note: Family work variables (family working/in school and family work schedule) were not

included in the final models due to high correlation with family work hours variable

Model 1: Demographic variables

Model 2: Demographic variables + family work characteristics

\section{Acknowledgements}

The authors would like to acknowledge an anonymous group of experts in the field who provided guidance and support for our work.

\section{Authors' contributions}

LH analyzed the data and was primarily responsible for writing the manuscript. LF and AG were involved in conceptualization of the project, writing, and reviewing the final manuscript. All authors read and approved the final manuscript.

\section{Funding}

The research was funded through an agreement with Employment and Social Development Canada (ESDC). However, $L H, L F$, and $A C$ were responsible for the study design, analysis, and interpretation of findings. The opinions expressed in this report are those of the authors and not Statistics Canada or ESDC.

\section{Availability of data and materials}

General Social Survey 2011 data are available through Statistics Canada's Research Data Centres (statcan.gc.ca/eng/ microdata/data-centres); however, the T1FF-linked files that support the findings of this study are not publically available. 


\section{Competing interests}

The authors declare that they do not have any competing interests.

Received: 15 April 2020 Accepted: 24 August 2020

Published online: 11 September 2020

\section{References}

Cleveland, G., \& Gunderson, M. (1996). Child care costs and the employment decision of women: Canadian evidence. Canadian Journal of Economics, 29(1), 132-151.

Financial Accountability Office of Ontario. (2019). Child care in Ontario: A review of Ontario's new child care tax credit and implications for Ontario's labour force.

Findlay, L., \& Kohen, D. (2019). GSS2011 Linked with T1FF: Exploring the cost of child care in Canada and the use of the child care tax benefit. Can J Fam Youth, 12(1), 81-103.

Haeck, C., Lefebvre, P., \& Merrigan, P. (2015). Canadian evidence on ten years of universal preschool policies: The good and the bad. Labour Econ, 36, 137-157.

Laurin, A., \& Milligan, K. (2017). Tax Options for Childcare that Encourage Work, Flexibility, Choice (p. 481). Howe Institute Commentary No: Fairness and Quality. C.D.

Lefebvre, P., Merrigan, P., \& Verstraete, M. (2009). Dynamic Labour supply effects of childcare subsidies: evidence from a Canadian natural experiment on low-free universal child care. Labour Econ, 15, 490-502.

Macdonald, D., \& Friendly, M. (2014). The Parent Trap: Child Care Fees in Canada's Big Cities. Canadian Centre for Policy Alternatives.

Macdonald, D., \& Friendly, M. (2018). A Growing Concern: 2016 Child Care Fees in Canada's Big Cities. Canadian Centre for Policy Alternatives

Melhuish E, Ereky-Stevens K, Petrogiannis K, Ariescu A, Penderi E, Rentzou K, et al. (2015). A Review of research on the effects of early childhood education and care (ECEC) on child development. Child Care Canada Childcare Resource and Research Unit Report.

National Survey of Early Care and Education Project Team. (2014). Household Search for and Perceptions of Early Care and Education: Initial Findings from the National Survey of Early Care and Education (NSECE). OPRE Report No. 2014-55a. Washington, DC: Office of Planning, Research and Evaluation, Administration for Children and Families, U.S. Department of Health and Human Services.

Spence, J. C., Holt, N. L., Dutove, J. K., \& Carson, V. (2010). Uptake and Effectiveness of the Children's Fitness Tax Credit in Canada: the richer get richer. BMC Public Health, 10, 356

Statistics Canada. (2019). Survey on Early Learning and Child Care Arrangements, 2019. The Daily April 10. Statistics Canada Catalogue no. 11-001-X.1-7.

Statistics Canada. (2011). Census Dictionary. Statistics Canada Catalogue no. 98-301-X2011001.

Yoshikawa, H., Weiland, C., Brooks-Gunn, J., Burchinal, M. R., Espinosa, L. M., Gormley, W. T., et al. (2013). Investing in our Future: The evidence base on preschool education. Foundation for Child Development: Society for Research in Child Development.

\section{Publisher's Note}

Springer Nature remains neutral with regard to jurisdictional claims in published maps and institutional affiliations.

\section{Submit your manuscript to a SpringerOpen ${ }^{\circ}$ journal and benefit from:}

- Convenient online submission

Rigorous peer review

- Open access: articles freely available online

- High visibility within the field

- Retaining the copyright to your article

Submit your next manuscript at $\boldsymbol{\Delta}$ springeropen.com 